\title{
Improvement of Science Learning Achievement in Animal and Plant Material in My Home Environment in SDN Karanggintung 07
}

\author{
Rotiah \\ SDN Karanggintung 07 \\ rotiahantaraos@gmail.com
}

\section{Article History}

accepted 14/11/2020

\begin{abstract}
This study aims to describe efforts to improve science learning achievement through the use of IT-based learning media (technology science) in grade IV students, to improve science learning achievement through the use of IT-based learning media (Technology Science) in grade IV SDN Karanggintung 07. This research uses based media. IT (Science of Technology) and consists of four stages, namely planning, implementing, observing, and reflecting. The subjects of this study were 18 grade IV students at SDN Karanggintung 07. Data collection techniques used observation sheets and written tests. The results of this study showed A significant increase was seen in the pre-cycle value of students who reached KKM only 50\%, after cycle 1 increased to $55.55 \%$, cycle II $66.66 \%$ and the peak in cycle III reached $83.33 \%$. Thus the use of IT-based media (Technology Science) can improve the learning achievement of fourth grade students in science subjects animal and tumb God in my neighborhood.
\end{abstract}

Keywords: Learning achievement, learning Media, technology science

\begin{abstract}
Abstrak
Penelitian ini bertujuan Mendeskripsikan upaya peningkatan prestasi belajar IPA melalui penggunaan media pembelajaran berbasis IT(ilmu teknologi) pada siswa kelas IV, Meningkatkan prestasi belajar IPA melalui penggunaan media pembelajaran berbasis IT(IImu Teknologi) pada siswa kelas IV SDN Karanggintung 07.Penelitian mengggunakan media berbasis IT(IImu Teknologi) dan terdiri dari empat tahap yaitu perencanaan,pelaksanaan,observasi,dan revleksi.Subjek penelitian ini adalah siswa kelas IV di SDN Karanggintung 07 yang berjumlah 18 siswa.Teknik pengumpulan data menggunakan lembar observasi dan tes tertulis. Hasil penelitian ini menunjukan peningkatan yang signifikan terlihat pada pra siklus nilai siswa yang mencapai KKM hanya 50\%,setelah siklus 1 meningkat menjadi 55,55\%,siklus II 66,66\% dan puncaknya di siklus III yaitu mencapai $83,33 \%$.Dengan demikian penggunaan media berbasis IT(IImu Teknologi)dapat meningkatkan prestasi belajar siswa kelas IV pada mata pelajaran IPA materi hewan dan tumbuhan di lingkungan rumahku.
\end{abstract}

Kata kunci: Prestasi belajar,media pembelajaran,ilmu teknologi

Social, Humanities, and Education Studies (SHEs): Conference Series https://jurnal.uns.ac.id/shes

p-ISSN 2620-9284

e-ISSN 2620-9292 


\section{PENDAHULUAN}

Pendidikan merupakan sarana untuk memperkuat jati diri bangsa dalam proses industrialisasi dan mendorong terjadinya perubahan masyarakat Indonesia dalam memasuki era globalisasi. Pendidikan harus mengantisipasi kemunginan kejadian yang akan terjadi di masa depan, sehingga perlu pembekalan dalam berbagai kompetensi bagi peserta didik (Mulyasa, 2013:16). Pembekalan dalam berbagai kompetensi dapat dilakukan melalui jalur pendidikan formal yaitu sekolah

Sekolah merupakan lingkungan yang sengaja diciptakan untuk membina anakanak ke arah tujuan tertentu, khususnya untuk memberikan kemampuan dan keterampilan sebagai bekal kehidupan di kemudian hari. Sekolah dipandang sebagai lembaga yang cukup berpengaruh terhadap terbentuknya konsep yang berkenaan dengan nasib di masa depan. Jika prestasi atau hasil yang dicapai di sekolah itu baik, maka kemungkinan kehidupan pada masa depan menjadi cerah (Sunarto \& Hartono, 2008:195). Proses kegiatan belajar mengajar di sekolah inilah, yang menjadi kunci keberhasilan dalam meraih prestasi.

Proses kegiatan belajar mengajar di sekolah erat kaitannya dengan pemilihan metode atau media pembelajaran yang sesuai dengan minat dan karakteristik siswa. Menurut Darling (dalam Supratiknya, 2006:60) menjelaskan bahwa pembelajaran setiap mata pelajaran perlu bertolak dan dikaitkan dengan minat siswa. Guru harus kreatif dan berwawasan luas dalam mengangkat sesuatu topik aktual dalam kehidupan siswa, sebagai sarana kegiatan pembelajaran yang akan membangkitkan motivasi dan perhatian. Bila siswa memperhatikan, maka siswa belajar. Bila siswa belajar dengan senang dan bersemangat, maka prestasi belajar siswa dapat meningkat.

Metode atau media pembelajaran yang digunakan oleh guru dalam mengajar merupakan cara atau perantara dalam menyampaikan materi pembelajaran kepada siswa di sekolah. Metode atau media pembelajaran selalu bervariasi, memiliki karakteristik dan berkembang sesuai dengan perkembangan zaman. Perkembangan zaman berhubungan dengan Teknologi, Informasi, \& Komunikasi (TIK). Hal ini diungkapkan oleh Mulyasa (2013:16) yang menyatakan bahwa kegiatan belajar mengajar di masa sekarang dan masa depan tidak akan lepas dari ilmu tentang teknologi informasi. Berkembangnya ilmu dan teknologi, memberikan perubahan pada learning material atau bahan belajar. Berkembangnya teknologi komputer sebagai bahan belajar yang pokok digunakan dalam dunia pendidikan adalah semua yang bersifat printed material,seperti buku,modul,makalah, majalah, koran, tabloid, jurnal, dan sebagainya yang menggunakan bahan tercetak.

Perubahan dalam bidang teknologi khususnya teknologi informasi, memberikan alternatif bahan belajar berupa program/software yang dapat dimanfaatkan dalam membuat data, mengambil data, membaca, download bahkan sampai interaksi antara program dengan siswa dan guru, dengan memanfaatkan komputer sebagai perangkat utama. Komputer tidak hanya dimaknai sebagai ilmu yang baru dipelajari siswa (computer as science), tetapi komputer sebagai alat yang membantu untuk mempelajari berbagai materi pembelajaran atau computer as tools (Mulyasa, 2013:16). Materi pembelajaran dapat berupa materi pada mata pelajaran yang ada di sekolah misalnya Ilmu Pengetahuan Alam (IPA).

IPA adalah pengetahuan yang sistematis dan dirumuskan, yang berhubungan dengan gejala-gejala kebendaan dan didasarkan terutama atas pengamatan dan dedukasi. IPA mempelajari alam semesta, benda-benda yang ada di permukaan bumi, di dalam perut bumi dan di luar angkasa, baik yang dapat diamati indera maupun yang tidak dapat diamati dengan indera. Materi pembelajaran IPA yang dapat diamati dengan indera, lahir dan berkembang melalui metode ilmiah seperti observasi dan eksperimen serta menuntut sikap ilmiah seperti rasa ingin tahu, terbuka, jujur, dan sebagainya (Trianto, 2010:136-137). Materi pembelajaran IPA yang tidak dapat diamati langsung oleh indera dilakukan dengan salah satu cara misalnya dengan 
menggunakan media pembelajaran. Mempelajari IPA dibutuhkan rasa ingin tahu dan keinginan untuk mempelajarinya. Salah satu hal yang diperlukan untuk mencapai hal tersebut ialah memiliki motivasi belajar terhadap mata pelajaran IPA. dibutuhkan rasa ingin tahu dan keinginan untuk mempelajarinya. Salah satu hal yang diperlukan untuk mencapai hal tersebut ialah media yang menarik dan tepat terhadap mata pelajaran IPA.

IPA adalah pengetahuan yang sistematis dan dirumuskan, yang berhubungan dengan gejala-gejala kebendaan dan didasarkan terutama atas pengamatan dan dedukasi. IPA mempelajari alam semesta, benda-benda yang ada di permukaan bumi, di dalam perut bumi dan di luar angkasa, baik yang dapat diamati indera maupun yang tidak dapat diamati dengan indera. Materi pembelajaran IPA yang dapat diamati dengan indera, lahir dan berkembang melalui metode ilmiah seperti observasi dan eksperimen serta menuntut sikap ilmiah seperti rasa ingin tahu, terbuka, jujur, dan sebagainya (Trianto, 2010:136-137). Materi pembelajaran IPA yang tidak dapat diamati langsung oleh indera dilakukan dengan salah satu cara misalnya dengan menggunakan media pembelajaran. Mempelajari IPA dibutuhkan rasa ingin tahu dan keinginan untuk mempelajarinya. Salah satu hal yang diperlukan untuk mencapai hal tersebut ialah memiliki motivasi belajar terhadap mata pelajaran IPA. dibutuhkan rasa ingin tahu dan keinginan untuk mempelajarinya. Salah satu hal yang diperlukan untuk mencapai hal tersebut ialah media yang menarik dan tepat terhadap mata pelajaran IPA.

Media pembelajaran adalah suatu cara, alat, atau proses yang digunakan untuk menyampaikan pesan dari sumber pesan kepada penerima pesan yang berlangsung dalam proses pendidikan. Penggunaan media pembelajaran dalam proses belajar mengajar dapat membangkitkan keinginan dan minat yang baru, membangkitkan motivasi dan rangsangan kegiatan belajar. Media pembelajaran juga dapat membantu siswa meningkatkan pemahaman, menyajikan data dengan menarik dan terpercaya, memudahkan penafsiran, serta memadatkan informasi (Angkowo \& Kosasih, 2007:14).

\section{METODE}

Penelitian ini akan dilaksanakan di kelas IV SDN Karanggintung 07 dengan subjek penelitian siswa dan guru. Siswa kelas IV berjumlah 18 anak yang terdiri dari 9 siswa laki- laki dan 9 siswa perempuan. Penelitian tindakan kelas ini dilaksanakan pada siswa kelas IV SDN Karanggintung 07 yang terletak di Desa Karanggintung Kecamatan Gandrungmangu Kabupaten Cilacap.

Pelaksanaan penelitian siklus I dilaksanaan pada hari Kamis 12 November 2020. Penelitian pada siklus I ini dilakukan sesuai dengan progam semester mata pelajaran IPA Tema 3 subtema 1. Pelaksanaan siklus I ini dilaksanakan dalam empat tahapan, yaitu perencanaantindakan, pelaksanaan tindakan, observasi, dan refleksi. Kegiatan pembelajaran yang dilakukan pada siklus II secara umum tidak jauh berbeda dengan siklus I. Hal yang membedakan adalah pemberian tindakan melihat dari refleksi yang telah dilakukan pada siklus I.

Peneliti memperbaiki kekurangan pada siklus II. Pembelajaran siklus III ini peneliti terlebih dahulu menyiapkan instrumen penelitian seperti: RPP, LKPD, Soal evaluasi, lembar observasi, bahan ajar berupa power point interaktif dan video pembelajaran yang sesuai dengan media pembelajaran berbasis IT yang digunakan dalam penelitian ini. Peneliti kemudian menyiapkan kelas untuk melaksanakan penelitian. Membuat rincian kegiatan pembelajaran dan mempersiapkan media pembelajaran yang diperlukan dalam pelaksanaan penelitian. 
HASIL DAN PEMBAHASAN

Peneliti melakukan pembelajaran siklus I dengan satu kali pertemuan,begitu pula dengan siklus 2 dan 3.Setiap siklus mengalami peningkatan hasil prestasi belajar siswa pada mapel IPA materi hewan dan tumbuhan di lingkungan rumahku.Dan penelitian ini berakhir pada siklus 3,berikut kami tampilkan data hasil prestasi belajar siswa persiklus:

Tabel 1. Peningkatan Hasil Belajar Siswa

\begin{tabular}{llllll}
\hline \multirow{2}{*}{ Pembelajaran } & \multicolumn{5}{c}{ Hasil belajar siswa } \\
\cline { 2 - 6 } & $\begin{array}{c}\text { Nilai rata- } \\
\text { rata kelas }\end{array}$ & Tuntas & Prosentase & Belum & Prosentase \\
\hline Pra siklus & 67,77 & 9 & $50 \%$ & 9 & $50 \%$ \\
\hline Siklus I & 76,66 & 10 & $55,55 \%$ & 8 & $44,45 \%$ \\
\hline Siklus II & 81,66 & 12 & $66,66 \%$ & 6 & $33,33 \%$ \\
\hline Siklus III & 85 & 15 & $83.33 \%$ & 3 & $16,67 \%$ \\
\hline
\end{tabular}

Berdasarkan Penelitian Tindakan Kelas pada siswa kelas IV SDN Karanggintung 07 diperoleh data hasil penelitian prestasi belajar, data prestasi akhir diperoleh melalui hasil soal evaluasi tes tertulis pada akhir pertemuan di setiap siklus. Penggunaan media pembelajaran berbasis IT dari kondisi awal hingga akhir siklus III terlihat adanya peningkatan motivasi dalam pembelajaran di kelas. Peningkatan ini dibuktikan dengan data hasil belajar siswa selama 3 kali siklus. Berdasarkan tabel terjadi peningkatan motivasi yaitu dari rata-rata kondisi awal 67,77 tergolong sedang, pada akhir siklus I meningkat menjadi 76,66 yang tergolong tinggi, dan pada akhir siklus III meningkat menjadi 85 yang tergolong tinggi. Dengan demikian target telah tercapai di siklus III.

\section{SIMPULAN}

Penggunaan media pembelajaran berbasis IT dapat meningkatkan prestasi belajar IPA materi hewan dan tumbuhan di lingkungan rumahku pada siswa kelas IV SDN Karanggintung 07 tahun ajaran 2020/2021. Hal ini ditunjukkan dengan adanya peningkatan persentase jumlah siswa yang mencapai KKM (72) dari kondisi awal $50 \%$ meningkat menjadi $55,55 \%$ pada akhir siklus I, dan meningkat menjadi $66,66 \%$ pada akhir siklus II,serta meningkat menjadi $83,33 \%$ pada siklus III.Nilai rata-rata meningkat dari kondisi awal 67,77 menjadi pada akhir siklus I, dan menjadi 76,66 pada akhir siklus II,serta menjadi 85 pada siklus III.

\section{DAFTAR PUSTAKA}

Angkowo, R \& Kosasih, A. (2007). Optimalisasi Media Pembelajaran. Jakarta: PT Grasindo.

Arifin, Z. (2009). Evaluasi Pembelajaran. Bandung: PT Remaja Rosdakarya Offset.

Arifin, Z. (2011). Model Penelitian dan Pengembangan. Bandung: PT Remaja Rosdakarya Offset.

Arikunto, S. (2010). Penelitian Tindakan untuk Guru, Kepala Sekolah dan Pengawas. Yogyakarta: Aditya Media.

Arikunto, S., Suhardjono, \& Supardi. (2009). Penelitian Tindakan Kelas. Jakarta: PT Bumi Angkasa.

Arsyad, A. (2010). Media Pembelajaran. Jakarta: Rajawali Pers. Buku guru dan siswa Tematik Tema 3 LKS Persada 